\title{
Theoretical Stereostructure of the Neutral Form of Natural Tetrahydrobiopterin
}

\author{
Setsuko Katoh ${ }^{\S}$, Terumi Sueoka, and Teruo Kurihara \\ Department of Biochemistry. Meikai University School of Dentistry, Sakado, Saitama 350-02, Japan \\ \# Department of Organic Chemistry, Faculty of Science, Josai University, Sakado, Saitama 350-02, Japan
}

(Received January 25, 1993)

\begin{abstract}
Summary
The absolute conformation and the reactivity of atoms of the neutral form of natural tetrahydrobiopterin [(6R)-6-(L-erythro-1',2'-dihydroxypropyl)-5,6.7.8-tetrahydropterin] was determined by the Molecular-Orbital method within the MINDO/3 framework. Two different conformations (Form A and Form B) of the alkyl side chain relative to the pterin ring were obtained as the optimized form for the lowest energy conformation $(\Delta \mathrm{H}=-174 \mathrm{kcal} / \mathrm{mol})$ of this molecular constitution with the same molecular width of $11.2 \AA$. Form $\mathrm{A}$ and $\mathrm{B}$ were distinguishable in the dihedral $\left[\mathrm{Ol}^{\prime}-\mathrm{Cl}^{\prime}-\mathrm{C} 6-\mathrm{H} 6\right]$ of $-88^{\circ}$ and $30^{\circ}$, respectively. Net charges of atoms of Form $\mathrm{A}$ and $\mathrm{B}$ suggested that the predominant reactivity of the atoms of N1, C2, C4, O4, $\mathrm{C} 4 \mathrm{a}$, and $\mathrm{C} 8 \mathrm{a}$ of the pterin ring and $\mathrm{C}^{\prime}, \mathrm{C}^{\prime}$. $\mathrm{Ol}^{\prime}$ and $\mathrm{O}^{\prime}$ of the side chain. It was also suggested that the position $2^{\prime}$ is more active than the position $\mathrm{l}^{\prime}$. in the alkyl side chain of Form A and B, toward $\mathrm{NADP}+$ in the reverse reaction of sepiapterin reductase.
\end{abstract}

Key words: 6(R)-tetrahydrobiopterin, Neutral form, Absolute conformation, Molecular-orbital method, Atomic net charge

\section{Introduction}

Tetrahydrobiopterin $\quad\left[6-\left(1^{\prime} .2^{\prime}\right.\right.$-dihydroxypropyl $)-5.6$ 7,8-tetrahydropterin: $\mathrm{BH}_{4}$ ] (Fig. 1) is an important naturally occurring substance controlling the level of phenylalanine in the liver or biogenic monoamines in neural tissues (1). In addition to this established role, several other new physiological activities of $\mathrm{BH}_{4}$ have recently been proposed. These are, for example, as a factor required for the synthesis of nitrogen oxide, the endothelium-derived relaxing factor (EDRF) in the conversion of arginine to citrulline in macrophages $(2,3)$, and as a factor involved in the mechanism of dopamine release in the brain through a specific receptor (4).

Of the total of eight configurational isomers of the $\mathrm{BH}_{4}$ molecule (Fig. 1), naturally-occurring $\mathrm{BH}_{4}$ cofactor in mammals is the 6R-L-erythro form (idiomatically referred to as $6 \mathrm{R}-\mathrm{BH}_{4}$ ). The stereochemistry

\footnotetext{
${ }^{\S}$ Author to whom correspondence should be addressed.
}

of the ring structure and the alkyl side chain of the natural $\mathrm{BH}_{4}$ supplies specific regulatory function to the molecule. Enzymes or receptors associated with $\mathrm{BH}_{4}$ activity may have specific domains fitted to the stereostructure of $6 \mathrm{R}-\mathrm{BH}_{4}$.

The stereochemistry of $6 \mathrm{R}-\mathrm{BH}_{4}$ molecule was previously studied by $N M R$ and $C D$ analyses (5-7) at acidic $\mathrm{pH}$ and its absolute conformation was determined by X-ray analysis (5) with dihydrochloride crystals. In these studies, the atoms of N5 or N1. and $\mathrm{N} 5$ of the $\mathrm{BH}_{4}$ molecule were protonated. The neutral form of $6 \mathrm{R}-\mathrm{BH}_{4}$ at physiological $\mathrm{pH}$, however, is quite labile under aerobic conditions. and its exact stereostructure is unclear. In the present study, we determined the absolute conformation and the reactivity of the constituting atoms of the neutral form of $6 \mathrm{R}^{-} \mathrm{BH}_{4}$ by the Molecular-Orbital Method to know the physiological conformation of it. 


\section{Methods}

The formal chemical structure of $6 \mathrm{R}-\mathrm{BH}_{4}$ is $(6 \mathrm{R}$, 1'R, 2'S)-6-(1', 2'-dihydroxypropyl)-5,6,7,8-tetrahydropterin (Fig. 1). For optimisation of the conformation of the $6 \mathrm{R}-\mathrm{BH}_{4}$ molecule, the ring structure of tetrahydropterin in half-chair conformation and the $\mathrm{R}$ configuration of equatorial substitution of the alkyl side chain at position $\mathrm{C} 6$ on the ring were set up in accordance with the results of previous physical analyses of $6 \mathrm{R}^{-\mathrm{BH}_{4}}$ structure (5-7) and the determination of theoretical structure of 6-pyruvoyl tetrahydropterin (8), a metabolic precursor of $6 \mathrm{R}-\mathrm{BH}_{4}$. The two hydroxyl groups at $1^{\prime}$ and $2^{\prime}$ positions were set up in the trans form around the $\mathrm{Cl}^{\prime}-\mathrm{C}^{\prime}$ bond as the most stable conformation. The first optimisation was performed for the conformation in which the bonds of $\mathrm{Ol}^{\prime}-\mathrm{Cl}^{\prime}$ and $\mathrm{C} 6-\mathrm{H} 6$ were in the trans position. The alkyl side chain. in the optimized form. was rotated relative to the pterin ring at intervals of $30^{\circ}$, and the geometry was optimized at each point. The dihedral $\mathrm{Ol}^{\prime}-\mathrm{Cl}^{\prime}-\mathrm{C} 6-\mathrm{H} 6$ was the reaction coordinate. The lowest energy conformation of the results was applied to the final optimisation.

Calculations were performed with the MOPAC on an FACOM M-360/MSP computer. The geometries were optimized within the $\mathrm{MINDO} / 3$ framework (9).

(a)

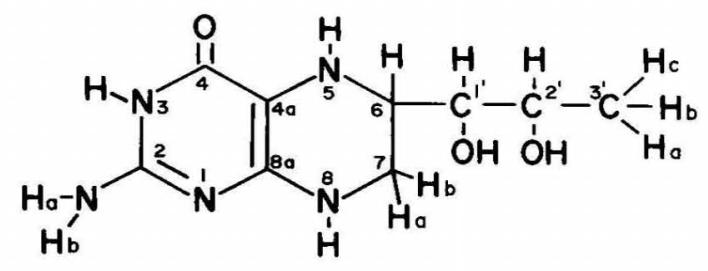

(b)
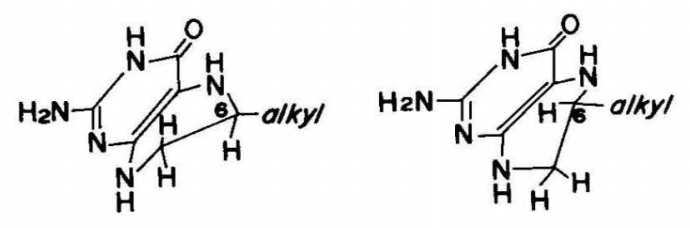

(6R)-

(6S)-

(c)

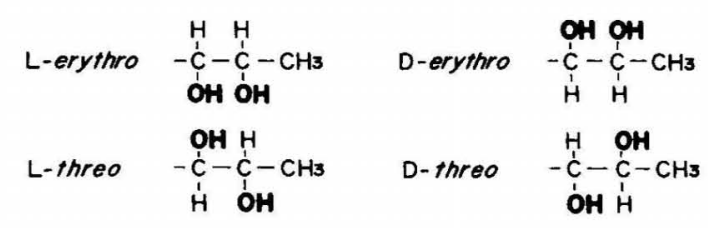

Figure 1. Tetrahydrobiopterin: (a) Natural type (6R-L-enthro form), (b) R \& S enantiomers, and (c) Four epimers of the alkyl group.

\section{Results and Discussion}

The MO-calculation of the $\mathrm{BH}_{4}$ molecule is quite complicated since the molecule has a total of three chiral centers at $\mathrm{C} 6, \mathrm{Cl}^{\prime}$, and $\mathrm{C}^{\prime}$ (Fig. 1). There are $\mathrm{R}$ and $\mathrm{S}$ enantiomers for the attachment of the alkyl side chain to the pterin ring at C6. The second and third chiral centers, $\mathrm{Cl}^{\prime}$ and $\mathrm{C}^{\prime}$, introduce four diastereoisomers of the side chain (L-erythro, L-threo, $\mathrm{D}$-threo, and D-erythro forms) for each of the $\mathrm{R}$ and $\mathrm{S}$ enantiomers.

Molecular-Orbital calculations within the MI$\mathrm{NDO} / 3$ framework of the neutral molecule of $6 \mathrm{R}$ $\mathrm{BH}_{4}$ (the 6(R)-L-erythro epimer) optimized two different conformations (Form A and Form B) as the lowest energy conformer $(\Delta \mathrm{H}=-174 \mathrm{kcal} / \mathrm{mol})(\mathrm{Ta}-$ ble 1). Fig. $2 a$ and $b$ show their optimized geometries and stereostructures by computer generating (10), respectively. The side chain attached to $\mathrm{C} 6$ in Form $\mathrm{A}$ and Form B took the equatorial conformation with a different dihedral of the $\mathrm{Ol}^{\prime}-\mathrm{Cl}^{\prime}$ bond around the $\mathrm{Cl}^{\prime}-\mathrm{C} 6$ bond $\left[\mathrm{Ol}^{\prime}-\mathrm{Cl}^{\prime}-\mathrm{C} 6-\mathrm{H} 6\right]$ of $-88^{\circ}$ and $30^{\circ}$, respectively (Table 1 ). These conformations were different from that of $6 \mathrm{R}-\mathrm{BH}_{4}$ dihydrochloride of which analytical value of that dihedral was not mentioned but apparently suspected to be almost $180^{\circ}$ from its perspective drawing structure (5). The planar structure of the pterin ring except C6 ( $\Theta[\mathrm{C} 4-\mathrm{C} 4 \mathrm{a}-\mathrm{N} 5$ C6 $]=-157.8^{\circ}$ and $-159.4^{\circ}$ in Form $A$ and B. respectively) of these forms was quite similar to those structures of 6-pyruvoyl tetrahydropterin (8) and 6-methyl tetrahydropterin (11) analyzed by the MO-method. and $6 \mathrm{R}^{-\mathrm{BH}_{4}}$ dihydrochloride determined by X-ray diffraction (5). The conformation around the $\mathrm{C} 1^{\prime}-\mathrm{C} 2^{\prime}$ bond of each form was trans $\left(\Theta\left[C 3^{\prime}-\mathrm{C}^{\prime}-\mathrm{C} 1^{\prime}-\mathrm{C} 6\right]=-168^{\circ}\right.$ and $169^{\circ}$ in Forms A and $\mathrm{B}$, respectively) (Table 1 ) as in $6 \mathrm{R}-\mathrm{BH}_{4}$ dihydrochloride $\left(\Theta=174^{\circ}\right)(5)$. Two hydroxyl groups in the

Table 1. Optimized geometry of 6R-L-erythro-tetrahydrobiopterin.

\begin{tabular}{lrr}
\hline & Form A & \multicolumn{1}{c}{ Form B } \\
\hline$\Theta\left[=\mathrm{Ol}^{\prime}-\mathrm{Cl}^{\prime}-\mathrm{C} 6-\mathrm{H} 6\right]$ & $-88.28^{\circ}$ & \multicolumn{1}{c}{$30.42^{\circ}$} \\
$\Theta\left[=\mathrm{O}^{\prime}-\mathrm{C}^{\prime}-\mathrm{Cl}^{\prime}-\mathrm{O} 1^{\prime}\right]$ & $-164.82^{\circ}$ & $176.23^{\circ}$ \\
$\Theta\left[=\mathrm{C}^{\prime}-\left(2^{\prime}-\mathrm{Cl} 1^{\prime}-\mathrm{C} 6\right]\right.$ & $-167.95^{\circ}$ & $168.86^{\circ}$ \\
Molecular width $\left[\mathrm{H} 2 \mathrm{a}-\mathrm{H} 3^{\prime} \mathrm{b}\right]$ & $11.236 \AA$ & $11.254 \AA$ \\
\hline Formation energy: & & \\
$\Delta \mathrm{H} \mathrm{(kcal/mol)}$ & -174.21358 & -174.45627 \\
$\quad(\mathrm{~kJ} / \mathrm{mol})$ & -729.95484 & -730.97168 \\
Electronic energy (eV) & -19717.31579 & -19773.28895 \\
Core-core Repulsion (cV) & 16455.36527 & 16511.32790 \\
Total energy: F (eV) & -3261.95052 & -3261.96105 \\
Inonization potential & 7.20370 & 7.10501 \\
\hline
\end{tabular}


Form A

(a)

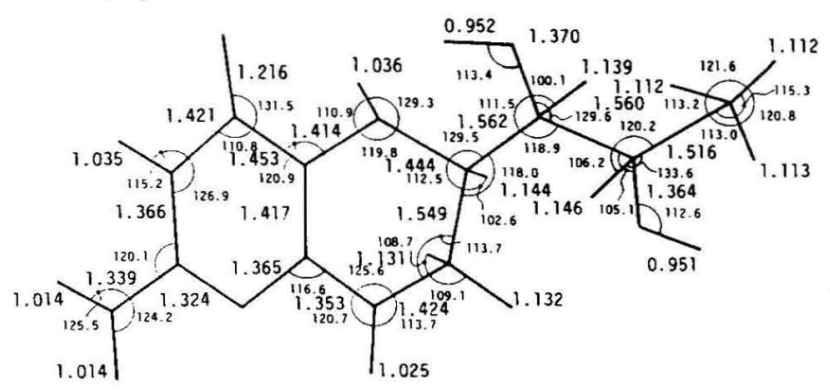

(b)

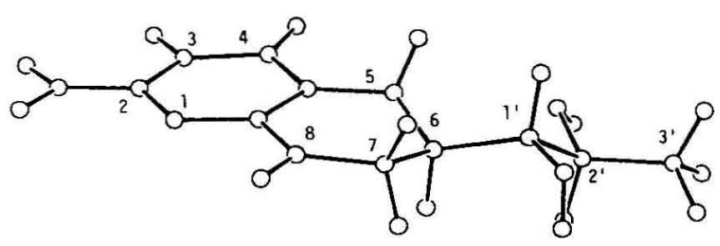

(c)
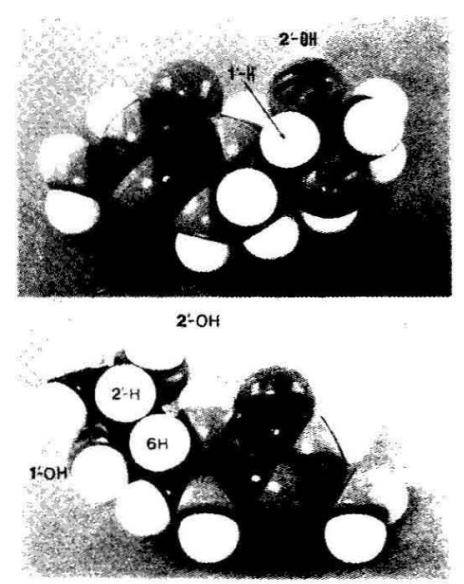

Form B
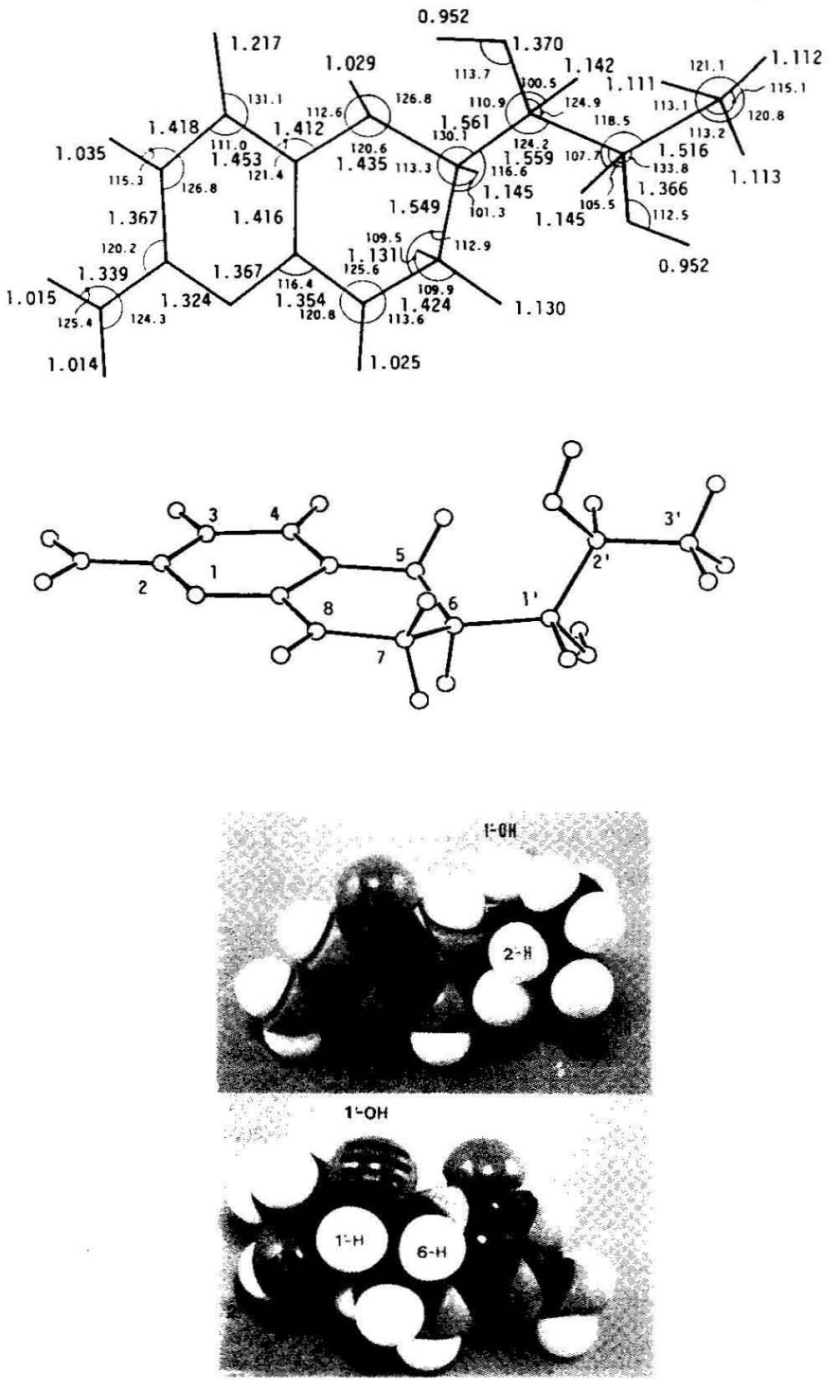

Figure 2. Perspective views of the optimized molecules of the neutral form of 6R-I.enthro tetrahydrobiopterin. (a) Optimized geometries (Bond lengths. $\AA$ and angles in small letters. deg.). (h) Computer-drawings. and (c) CPK-Modelings.

side chain of Form $\mathrm{A}$ and $\mathrm{B}$ were in trans around the $\mathrm{C} 1^{\prime}-\mathrm{C} 2^{\prime}$ bond $\left(\Theta=-164^{\circ}\right.$ and $176^{\circ}$. respectively) and the molecular width $\left(\mathrm{H} 2 \mathrm{a}-\mathrm{H} 3^{\prime} \mathrm{b}\right)$ of the Form $\mathrm{A}$ and $\mathrm{B}$ was the same. 11.2 $\AA$. (Table 1).

Form $\mathrm{A}$ and $\mathrm{B}$ were structured by the C PK-Model (Fig. 2c). Two oxygen atoms in the side chain of Form A apparently located on the same side of the pterin ring, while those of Form $\mathrm{B}$ were on the back side of the ring.

These structures were compared with the theoretical structures of tetrahydropterins involved in the biosynthesis of $6 \mathrm{R}-\mathrm{BH}_{4}$. Since $6 \mathrm{R}-\mathrm{BH}_{4}$ is formed from 6-pyruvoyl tetrahydropterin by the function of sepiapterin reductase with NADPH (12-15) in the biosynthesis from GTP. besides 6-pyruvoyl tetrahydropterin in the previous study (8). the lowest energy conformations of 6-lactoyl tetrahydropterin $(\Delta \mathrm{H}=$ $-165.23 \mathrm{kcal} / \mathrm{mol}$ ) and 6-hydroxyacetonyl tetrahydropterin $(\Delta \mathrm{H}=-162.22 \mathrm{kcal} / \mathrm{mol})$, which are hydroxyketo intermediates observed in the conversion of 6pyruvoyl tetrahydropterin into $6 \mathrm{R}-\mathrm{BH}_{4}$ by the enzyme (15), have been determined by the same framework (conformational data were not shown). The result implies that Form $\mathrm{A}$ is a more favorable conformation of a natural $6 \mathrm{R}-\mathrm{BH}_{4}$ than Form B.

Net charges of atoms of Form A and B molecules 
Table 2. Net charges of atoms constituting the neutral form of $6 \mathrm{R}$-L-erythro-tetrahydrobiopterin.

\begin{tabular}{l|ll||l|ll}
\hline Atoms & Form A & Form B & Atoms & Form A & Form B \\
\hline $\mathrm{N} 1$ & -0.40 & -0.40 & $\mathrm{H} 7 \mathrm{~b}$ & -0.06 & -0.06 \\
$\mathrm{C} 2$ & +0.44 & +0.43 & $\mathrm{~N} 8$ & -0.13 & -0.13 \\
$\mathrm{~N} 2$ & -0.19 & -0.19 & $\mathrm{H} 8$ & +0.07 & +0.07 \\
$\mathrm{H} 2 \mathrm{a}$ & +0.10 & +0.09 & $\mathrm{C} 8 \mathrm{a}$ & +0.34 & +0.34 \\
$\mathrm{H} 2 \mathrm{~b}$ & +0.11 & +0.11 & $\mathrm{Cl}^{\prime}$ & +0.33 & +0.33 \\
$\mathrm{~N} 3$ & -0.25 & -0.25 & $\mathrm{H}^{\prime}$ & -0.04 & -0.06 \\
$\mathrm{H} 3$ & +0.08 & +0.08 & $\mathrm{Ol}^{\prime}$ & -0.49 & -0.48 \\
$\mathrm{C} 4$ & +0.66 & +0.66 & $\left(\mathrm{Ol}^{\prime}\right) \mathrm{H} 1^{\prime}$ & +0.24 & +0.25 \\
$\mathrm{O} 4$ & -0.58 & -0.59 & $\mathrm{C}^{\prime}$ & +0.36 & +0.36 \\
$\mathrm{C} 4 \mathrm{a}$ & -0.32 & -0.31 & $\mathrm{H}^{\prime}$ & -0.12 & -0.11 \\
$\mathrm{~N} 5$ & -0.08 & -0.10 & $\mathrm{O}^{\prime}$ & -0.48 & -0.49 \\
$\mathrm{H} 5$ & +0.04 & +0.04 & $\left(\mathrm{O}^{\prime}\right) \mathrm{H} 2^{\prime}$ & +0.25 & +0.25 \\
$\mathrm{C} 6$ & +0.10 & +0.11 & $\mathrm{C}^{\prime}$ & +0.01 & +0.01 \\
$\mathrm{H} 6$ & -0.07 & -0.05 & $\mathrm{H}^{\prime} \mathrm{a}$ & -0.01 & -0.02 \\
$\mathrm{C} 7$ & +0.18 & +0.17 & $\mathrm{H}^{\prime} \mathrm{b}$ & -0.01 & -0.01 \\
$\mathrm{H} 7 \mathrm{a}$ & -0.06 & -0.06 & $\mathrm{H}^{\prime} \mathrm{c}$ & -0.01 & -0.01 \\
\hline
\end{tabular}

were calculated (Table 2). The results indicate that $\mathrm{N1}, \mathrm{C} 2, \mathrm{C} 4, \mathrm{O} 4, \mathrm{C} 4 \mathrm{a}$, and $\mathrm{C} 8 \mathrm{a}$, which are atoms comprising the pyrimidine ring, and $\mathrm{Cl}^{\prime}, \mathrm{C}^{\prime}, \mathrm{Ol}^{\prime}$ and $\mathrm{O}^{\prime}$, which are in the side chain. were predominantly reactive than those of the other atoms of the molecule in Form A and B, as was seen in these corresponding atoms in 6-pyruvoyl tetrahydropterin (8). Atomic charges (absolute values) of $\mathrm{C} \& \mathrm{H}$ at position $2^{\prime}$ were predominant than those at position $\mathrm{I}^{\prime}$ of Form A and Form B (Table 2). This suggests that $\mathrm{H}^{\prime}$ is more active than $\mathrm{Hl}^{\prime}$ toward $\mathrm{NADP}^{+}$. and that 6-hydroxyacetonyl tetrahydropterin (katoh pterin, the 2 -keto type) may thus reasonably be the direct product from $6 \mathrm{R}-\mathrm{BH}_{4}$ as actually observed (14) in the reverse reaction (dehydrogenase reaction) of sepiapterin reductase.

Theoretical conformation of the $6 \mathrm{R}-\mathrm{BH}_{4}$ molecule in its neutral form was also predicted by other workers $(16,17)$ who used different tools than we did. As already described in Methods. the present study was performed by a semiempirical MO-method (MOPAC. MINDO/3 framework), and we surveyed the lowest energy conformation from the structure in solution that is in accord with experimental findings $(6,7.18)$ and general chemical considerations (19). Ayling et al. (16) might do as well but employed the Molecular Mechanics method for calculations. While the study by Ziegler et al. (17) was based on a combination of Molecular Mechanics (CHARMm) and semiempirical MO-(AMPAC. AM I framework) methods, and they surveyed the global minimum conformation from many families of possible gasphase structures. The perspective structure of the $6 \mathrm{R}^{-} \mathrm{BH}_{4}$ having the lowest energy conformation was illustrated in their reports $(16,17)$. In the former report (16). it was apparently similar to that of Form A (Fig. 2b). While, in the latter one (17), it was quite different from both of Form $\mathrm{A}$ and $\mathrm{B}$ obtained in our study (Fig. $2 \mathrm{~b} \& 2 \mathrm{c}$ ) since it has an axial $\mathrm{C} 6$ side chain.

Ayling et al. (16) indicated that the conformation of $6 \mathrm{R}-\mathrm{BH}_{4}$ has a hydrogen bond between $\mathrm{N} 5-\mathrm{H}$ and the $\mathrm{C}^{2}-\mathrm{O}$. In Form $\mathrm{A}$ and $\mathrm{B}$ in our study interatomic distances between $\mathrm{N} 5$ and $\mathrm{O}^{\prime}$ (and $\mathrm{Ol}^{\prime}$ ) were $2.99 \AA(3.66 \AA)$ and $3.35 \AA(3.17 \AA)$. respectively. Thus it is difficult to find any certain hydrogen bond in these forms. Ziegler et al. (17) did not find it either in the $6 \mathrm{R}-\mathrm{BH}_{4}$ having the lowest energy conformation as calculated by them. On the other hand, the result of net charge calculations for Form A and B (Table 2) suggest the possibility of hydrogen bonding between $1^{\prime}-\mathrm{OH}, 2^{\prime}-\mathrm{OH}$, or $\mathrm{Nl}$ and some atom contained in the immediate environment such as the $\mathrm{BH}_{4}$-fitting domain of enzymes. Both these groups (16.17), however, did not mention the detailed geometry and other theoretical properties about atoms constituting the optimized molecule of 6R-BH.

In the physiological role of natural $\mathrm{BH}_{4}$, the conformation of the $6(\mathrm{R})$-L-erythro-dihydroxypropyl side chain. besides that of the tetrahydropteridine ring. is critical for many aspects of enzyme regulation (20-22). 6R-BH $\mathrm{BH}_{4}$ is now a hopeful therapeutic agent for certain neurological diseases such as atypical phenylketonuria (PKU). Parkinson's disease. Alzheimer's disease, and autism. It is important to know the stereostructure and the reactivity of neutral form of $6 \mathrm{R}-\mathrm{BH}_{4}$ as the physiological form.

\section{Acknowledgements}

We wish to thank Dr. Sadao Matsuura of Fujita Health University for valuable discussion and critical reading of the manuscript.

\section{References}

1. Kaufman S. In: Cooper BA. Whitehead VM. eds. Chemistry and Biolog of Pteridines. Berlin-New York: Walter de Gruyter. 1986: 185-200)

2. Taych MA. Marletta MA. J Biol Chem 1989; 264: 19654196.58.

3. Kwon NS. Nathan (F: Stuchr I)J. J Biol Chem 1989: 264: 20496-2050).

4. Koshimura K. Miwa S. Lee K. Fujiwara M. Watanabe Y. J Neurochem 1990): 54: 1391-1397.

5. Matsuura S. Sugimoto T. Murata S. Sugawara Y. Iwasaki 
H. J Biochem 1985; 98: 1341-1348.

6. Armarego WLF, Waring P, Paal B. Aust J Chem 1982; 35: 785-793.

7. Armarego WLF, Randles D. Taguchi H. Eur J Biochem 1983: 135: 393-403.

8. Katoh S, Sueoka T, Kurihara T. Biochem Biophys Res Commun 1991; 176: 52-58.

9. Dewar Research Group. Stewart GJP. QCPE Bull 1988: 8: 86.

10. Johnson CK. ORTEP Report ORNL-3794 Oak Ridge National Laboratory. Tennessee, 1965.

11. Gready JE. J Mol Struct Theochem 1984: 109: 231-244.

12. Masada M, Akino M. Sueoka T, Katoh S. Biochim Biophys Acta 1985; 840: 235-244.

13. Milstien S. Kaufman S. Biochem Biophys Res Commun 1985; 128: 1099-1107.

14. Curtius H-Ch, Heintel D, Ghisla S, Kuster T, Leimbacher W. Niederwieser A. Eur J Biochem 1985; 148: 413-419.

15. Katoh S. Sueoka T. In: Curtius H-Ch. Ghisla S. Blau N. eds. Chemistry and Biology of Pteridines. 1989. BerlinNew York: Walter de Gruyter, 1990): 324-327.

16. Ayling JE. Dilard SB, Bailey SW. In: Blau N. Curtius
H-Ch, Levine RA, Cotton RGH, eds. Pteridines and Biogenic Amines in Neurology, Pediatrics and Immunology. Grosse Pointe: Lake Shore Publishing Company. 1991: 269-282.

17. Ziegler I. Borchert M. Heaney F. Davies AP. Boyle PH. Biochim Biophys Acta 1992; 1135: 330-334.

18. Ghisla S, Steinerstauch P, Hasler T, Blau N, Curtius HCh. In: Curtius H-Ch, Blau N. Levine, RA, eds. Unconugated Pterins and Related Biogenic Amines. Berlin-New York: Walter de Gruyter, 1987; 67-79.

19. Viscontini M. In: Curtius H-Ch, Blau N, Levine RA, eds. Biochemical and Clinical Aspects of Pteridines Vol. 2. Berlin-New York: Walter de Gruyter, 1983: 21-34.

20. Shiman R. In: Blakley RL, Benkovic SJ, eds. Folates and Pterins Vol. 2. New York: Wiley Interscience. 1985: 179249.

21. Kaufman S, Kaufman EE. ibid 1985; 251-352.

22. Bailey SW, Dillard SB, Chandrasekaran RY, Ayling JE In: Reddy CC, Hamilton GA. Madyastha KM. eds. Biological Oxidation Systems Vol. 1. San Diego: Academic Press. 1990; 257-274. 